\title{
BEHAVIOR OF USING THE FOOD MARKETPLACE SYSTEM IN THE NEW NORMAL ERA OF COVID-19 IN INDONESIA
}

\author{
Istianingsih \\ Faculty of Economics and Business, Universitas Bhayangkara Jakarta Raya, Jakarta, \\ Indonesia \\ Email Address: istianingsih@dsn.ubharajaya.ac.id
}

The obligation to keep a distance from other people due to the pandemic has changed human life patterns, especially in shopping for their primary needs, namely food. The presence of the food marketplace presents new hope in maintaining health and food availability without crowding with other people while shopping. The main problem that is often a concern of the public when shopping online is transaction security and the Ease of use of this food marketplace application. This research is the intensity of using the Food Marketplace in terms of Interest, transaction security, and Ease of use of this application.

Researchers analyzed the relationship between variables with the Structural equation model. Respondents who became this sample were 300 application users spread across various major cities in Indonesia.

This study's results provide a view that the intensity of the food marketplace's use has increased significantly during the new normal life.

This paper's primary value lies in providing a better understanding of consumer behavior in the Indonesian food marketplace that has not been previously researched. By examining the determinants of the intensity of marketplace use in the food sector, it is hoped that this can become the basis for further research.

Keywords: food marketplace, Interest, Ease of use, user security

\section{Research Background}

The Covid-19 pandemic, which devastated the world economy, including Indonesia, forced people to adapt to new conditions and behavior immediately. Now, digital activities are commanding the community's daily life and 
implementing social distancing to break the chain of transmission of the epidemic. The emergence of the Covid-19 Pandemic has also brought consequences on the rise of Christoph Busch's online market (2021) and accelerated consumers' shift to online market purchases. Christoph Busch (2021) also stated that the share of ecommerce sales to be $16.1 \%$ in the second quarter of 2020. Most of this increase in sales is related to electronic retail platforms such as Amazon, a marketplace where third-party sellers offer a wide variety of products.

A marketplace is where buyers and sellers conduct transactions electronically (S. Wang and N. P. Archer, 2007). Until now, the development of the marketplace platform continues to increase. Xing Wan; Nianxin Wan; Ben Shaw-Ching Liu. (2020) also state that there is increasing attention to the use of platforms in today's modern economy.. Their research shows that their practical design can help understand the importance of leveraging a marketplace platform strategy.

Meanwhile, in Indonesia, there are already several well-known and frequently used local marketplaces. such as Tokopedia, Bukalapak, Blibli, Shopee, and Lazada. The traditional distribution chain in Indonesia has been replaced by a market structure dominated by digital intermediaries or marketplaces. We can sell and buy a wide variety of products through the marketplace, including various food products. The emergence of the Covid19 pandemic has also triggered increased public awareness to start adopting a healthy lifestyle. A healthy lifestyle also has an impact on shopping habits in the food marketplace in Indonesia.

A series of surveys created by dailysocial.id (2020) and market research platform Populix discussed online shopping activities in Indonesia during the pandemic. Of the total respondents who answered the questionnaire, $67 \%$ chose to use the marketplace application to shop for groceries, and the remaining $33 \%$ did not use the application to buy food needs. The survey also provides an overview of seller applications that are used to meet daily grocery needs. Figure 1 presents the results of the dailySocial.id research.

The survey results show the rapid development of the use of the food marketplace in Indonesia. Although these developments have increased consumer choice, the online market has also opened up opportunities for unsafe and defective products to enter Indonesia's marketplace. Marketplace infrastructure security is an essential and severe study considering that $40 \%$ of cybercrimes originate from Indonesia. This security issue is important because the government does not yet have cybersecurity and resilience, so crime in cyberspace is rife. 
Cybercrimes in Indonesia are diverse, ranging from virtual money theft, spreading viruses to breaching confidential organizational data.

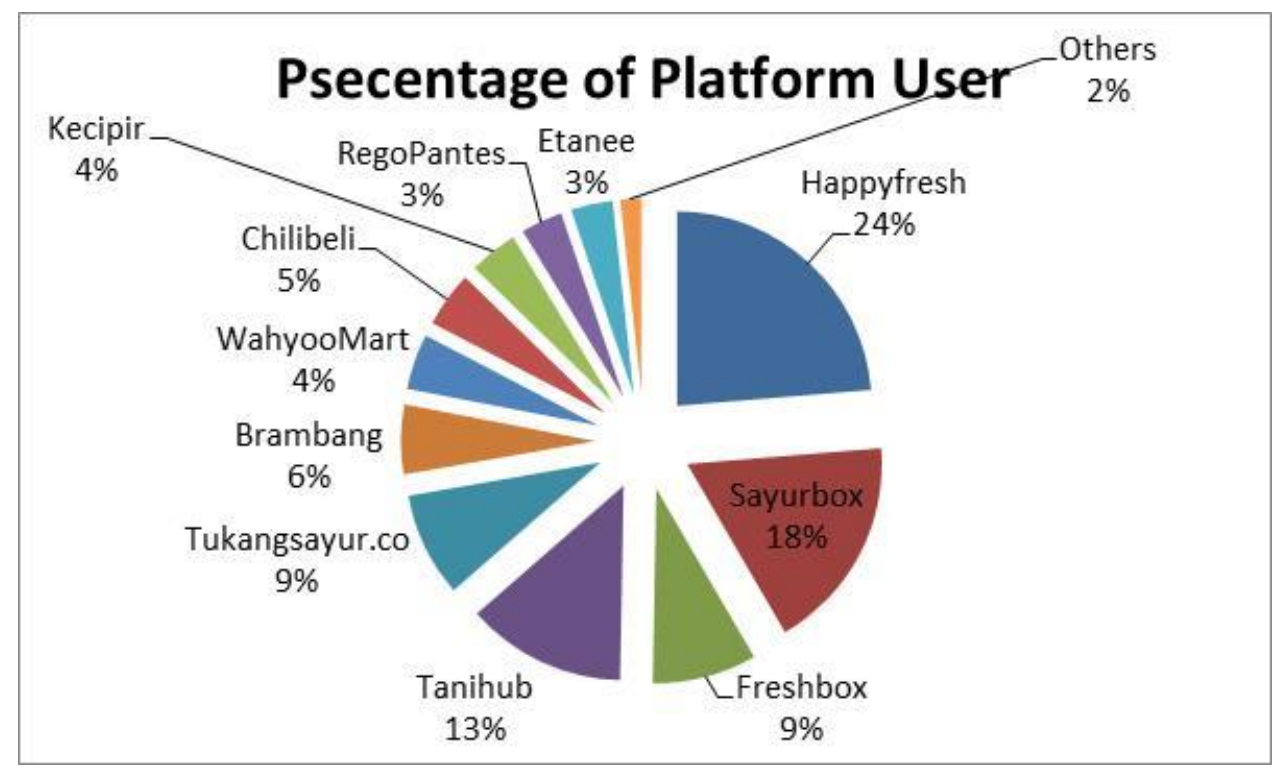

Figure 1. The intensity of the use of the food vendor application

Source: compiled from the results of dailySocial.id research 2020

On the other hand, the exchange of rich information between sellers and buyers provides an opportunity to increase the online market's competitiveness or marketplace. Li Chen's research results; Shandy Zhu (2021) found that sharing seller information positively affecting their business performance. Lavie (2006) states that sellers will also get sustainable profits by utilizing external resources, such as this marketplace. Wei, K., Li, Y., Zha, Y., and Ma, J. (2019) compared the intention to make transactions with consumers and sellers in terms of trust and risk on the $\mathrm{C} 2 \mathrm{C}$ marketplace platform. Their research results prove that buyers consider the problem of trust in the marketplace platform when transacting individually.

Zhi Yang, Zihe Diao, and Jun Kang (2020), researching from the perspective of marketplace platform builders, also suggest sustainable customer governance to improve enterprise platform performance. Thus the use of the food marketplace platform from the consumer side is essential to research. The controversial issue between developing social media applications in the online market and the negative possibilities is important for further analysis. The various factors that are predicted to influence the intensity of using the food marketplace platform have not been studied before in Indonesia.

The results of Adhi Prakosa's research (2021) show that shopping attitudes in the marketplace are not only influenced by the Ease of use but also by aspects of 
trust. As one of the psychological aspects that has a considerable influence on consumer behavior, Interest is also a motivation that will lead someone to use the food marketplace. Apart from interest, the desire to use the marketplace is also influenced by Ease's level in using the platform. When they use the marketplace system, the individual belief will be free from complicated efforts to increase the system's intensity. Maria (2019) examined Shopee's online shop's purchasing decisions and found that the Ease of transaction positively affects the online purchase interest variable.

Apart from these two factors, safety is a factor to consider in using the food marketplace. Maria's research (2019) found that Security does not affect the online purchase interest variable in the Shopee marketplace. However, the potential for crimes that commonly occur in online transactions such as fraud, credit card hijacking, illegal transfer of funds from certain accounts is tremendous if the security system of the marketplace infrastructure is still weak. Therefore, Security in accessing the food marketplace is an important study in this study.

This research's urgency lies in the use of the food marketplace, which is growing very rapidly, but so far, it has not been studied in Indonesia. This research is closely related to the development of information systems, especially in the e-Commerce field. It is expected to provide additional information and theory development related to the Influence of Interest, Ease, and Security, on the Food Marketplace System in the New Normal Covid-19 Era. This research is also expected to help users of the Food marketplace such as Tanihub, Agromaret, LimaKilo, and others that are very popular these days and a reference for developing start-up marketplaces that are engaged in Agribusiness and Online Food.

\section{Literature Review}

\subsection{Food Marketplace Platform}

Various kinds of online marketplaces in Indonesia specialize in different products and services. This study's food marketplace refers to an e-commerce platform that connects and facilitates transactions between individual sellers and buyers (Kestenbaum, 2017). Apart from the basic function of connecting sellers and buyers, this marketplace also facilitates communication between users. The online market usually also provides various social communication features for its users to share information.

According to Valtteri Kaartemo, Anna-Greta Nyström (2020), this market development is in the form of streams known as market formation (Baker, Storbacka, \& Brodie, 2019). This scheme describes the online market as a result of action designs that involve stakeholders to shape market innovation. As an innovation in the form of a marketplace institution, this is an actor's effort to change the market (Nenonen, Storbacka, \& FretheyBentham, 2019). As an 
institutionalized solution (Vargo \& Lusch, 2016), the marketplace develops along with technological developments (Vargo et al., 2017. The marketplace can adapt to the needs and framework of this platform. However, the marketplace changes from organizations' subjective perspectives or individuals interested in mapping a different market mean no objective marketplace definitions (Valtteri Kaartemo, Anna-Greta Nyström, 2020).

Several marketplaces made in local Indonesia with unique food concepts include Tanihub, which relies on various crops from local farmers of fresh vegetables and fruits. Moreover, the Lemonilo platform is also known as a marketplace that sells healthy instant noodles made from vegetables and a variety of healthy food menus. One more example of a well-known platform in Indonesia is Kecipir, which focuses on selling various foodstuffs such as rice, various vegetables, processed fish, and ready-to-eat shrimp.

\subsection{Consumer Interests and Use of the Food Marketplace}

Interest is a description of a person's situation before taking action, which can be used as a basis for predicting their behavior. Adhi Prakosa (2021) revealed that design of the e-marketplace application influence user to use it. Marketplace platforms in Indonesia usually create entertaining games and use bonus strategies to maximize the Interest in their loyal customers' personalization needs (Adhi Prakosa (2021). Maria (2019) shows that Security, Ease of transactions, and consumer confidence in the marketplace affect buying Interest on the Shopee platform. The higher a person's desire to be different through the marketplace, the more intense the intensity of using the food marketplace platform will increase. Thus this research proposes the following hypothesis:

\section{H1: Interest positively affect the decision to use the food marketplace platform}

\subsection{Perceived Ease of Use and Use of the Food Marketplace System}

Chin et al. (1995) show that perceived Ease of use is a determinant of user behavior in an information system. By implementing the technology acceptance model (TAM), Iqbaria, Guimaraes, and Davis (1995) showed the influence of Ease's variable level on the benefits of using information systems.

The results of Adhi Prakosa's research (2021) on the aspect of Ease of use show that there is an urgency for buyers to get free shipping on e-marketplaces. Adhi Prakosa's research results (2021) show that there is an urgency for buyers to get reduced shipping costs when shopping online. However, Adhi Prakosa (2021) also stated that all buyers do not feel the convenience of making online payments. 
Some people are reluctant to put money first in their account on online platforms to get certain discounts.

Maria (2019) failed to prove that the Ease of transactions using new technology affects the online purchase interest variable in the Shopee marketplace. L. CHEN AND F. ZHU (2020) states that the Ease of using technology will make consumers save time and energy, increasing the perceived usefulness of the User.

When someone believes that using a food marketplace platform is easy, its intensity will increase. The Ease of using this marketplace makes customers use it more often.

\section{H2: The Ease of using the platform has a positive effect on using the food marketplace.}

\subsection{Safety and Use of the Food Marketplace System}

Trust in the Security of the e-marketplace is an essential factor affecting the decision to use the application (M. Ridwan, T. Militina, and GN Achmad (2020). Trust is a level of protection against possible crimes that will occur when someone makes a transaction in terms of personal information security from the risk of fraud against marketplace service users. Parasuraman [5] states that the level of customer trust depends on the protection of their privacy. (Wei K., Li Y., Zha Y., Ma J., 2019) State that maintaining the privacy and customer security of their shopping accounts by not spreading confidential information about customers to any site is crucial. If a customer believes in an e-commerce site, he will believe that it will be safe and not distributed (M. Mayasari, Audina Audina . 2020).

If a customer wants to reduce the dangers of unseen transactions, they need to verify them on an ongoing basis ( (Mengwei Liu, Feng Gong, Ziqing Chen, Limei Yang, and Hui Lu, 2020). When the threat of transactions decreases, user confidence will increase (Adhi Prakosa (2021). With increasing trust due to reduced threats, users will also feel safer shopping using the food marketplace. The more secure the customer feels, the more intensity he uses the food marketplace platform in Indonesia.

\section{H3: Security has a positive effect on the use of the food marketplace platform.}

\subsection{Framework}

The framework in this study describes the influence of public interest in food marketplaces in Indonesia. The following framework also describes the relationship between the Ease and level of use of the marketplace platform. 
Besides, the following figure provides directions on the effect of Security on Indonesia's food marketplace level.

Figure 2. Research Conceptual Framework

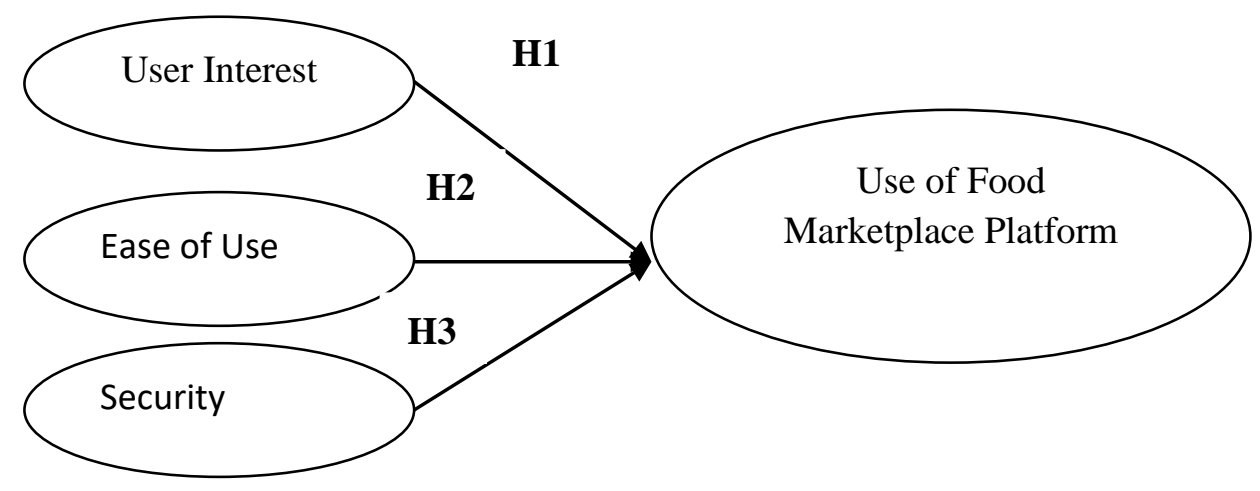

\subsubsection{Research Methods}

\subsection{Definition and Operations of Variables}

\subsubsection{Interest}

This study's variable of Interest is defined as a person's desire to use the digital food marketplace platform to shop for groceries. Interest variables are measured by four dimensions following Assael (2001), namely the emergence of interest due to transactions, references, preferences, and customers' exploration. The indicator for measuring Interest is

1) encouragement to make food Marketplace purchases

2) willingness to provide MarketPlace food recommendations

3 ) the primary choice of a product or service, which is the foremost preference of the food marketplace

4) desire to know food marketplace information

\subsubsection{Level of Ease of use}

The variable Ease of using the marketplace in this study is users' perception when they find it easy to use the e-marketplace. This Ease of use will impact user convenience to increase the intensity of using the food marketplace in Indonesia. Measurement of this variable follows Davis (1989) using the dimensions of easy to learn, clear and understandable, controllable, easy to become skillful, and flexible. The indicator for measuring this variable consists of the following questions:

1) Features in the Food Marketplace application can be used easily

2) Food Marketplace application is easy to get

3) Marketplace users can quickly operationalize Food Marketplace applications

4) Marketplace applications can use anywhere 
5) easy to make complaints or reviews on the Food Marketplace customer care features

\subsubsection{Security}

Security in this study is defined as a security guarantee where consumers get protection from threats from various irresponsible parties related to data confidentiality so that it is not spread to other parties. This variable dimension is data security and Marketplace User funds. The following questionnaire indicators measure these two dimensions:

1) The confidentiality of Marketplace User data is guaranteed by the user ID

2) The MarketPlace platform has guarantees for user funds

3) Funds belonging to the marketplace users will return if there is a discrepancy in the product purchased

\subsubsection{Use of the Food Marketplace Platform}

The use of the Food Marketplace Platform application in this study is the User's response to the application's offers. Measurement of this variable by looking at the respondent's answer to his experience using the application on the following indicator statements. "

1) I am interested in using the Food Marketplace again

2) I prefer Food Marketplace products over traditional markets

3) I want to recommend a Food Marketplace product to others

4) I use the Food Marketplace for the smooth running of my daily needs related to food

5) I place orders for foodstuffs from suppliers through the Food Marketplace

6) I can save time using the Food Marketplace

7) Using the Food Marketplace has become a lifestyle in today's digital era

8) Using the Food Marketplace makes it easier for me to compare prices and decide on food purchases

\subsection{Population and Research Sample}

This study's population is the Indonesian Community Users of the Food Marketplace System (Sayurbox, TukangSayur.co, Tanihub and HappyFresh. RegoPantes, Limakilo Etanee are other applications that sell vegetable, fruit, and livestock products directly to the final consumer). While the samples used are people who have used the Sayurbox Food Marketplace System, TukangSayur.co, Tanihub, and HappyFresh. RegoPantes, Limakilo, and Etanee are other applications that sell vegetable, fruit, and livestock products directly to the final consumer. This study's sampling technique is the Convenience Sampling technique by distributing questionnaires to Food Marketplace System Users using 
Google doc. Using multivariate analysis, this research's sample size should be five times the number of indicators for all construct variables (Hair et al., 2017). With the number of research parameters as many as 32 indicators in the questionnaire, the respondents' ideal number is between 160-320 respondents.

\subsection{Data Analysis Methods}

This study used a multivariate analysis approach to analyze the data with the Partial Least Square (PLS) tool's help. This research chose PLS to ensure better the validity and reliability of each variable's indicators (Hair, 2017). To test the instruments' validity and reliability, this study uses a model that describes the relationship between the indicators block and their construct. While the construct validity test in this study was measured by convergent and discriminant validity.To assess each indicator's convergent validity, it is assessed based on the loading factor's value that measures its construct (Hair, 2017). The cross-loading value is a measure of the discriminant validity of the construct variables under study.

The reliability test shows the accuracy, consistency, and precision of a measuring instrument in this study using two methods: Cronbach's Alpha and Composite Reliability. Cronbach's alpha measures the lower limit of a construct's reliability value, whereas composite reliability measures the real value of a construct's reliability (Chin, 1995). The reliability test shows the level of

accuracy and consistency of the measuring instrument. In addition to Cronbach's Alpha, this study also uses the following measure of Composite Reliability (Chin, 1995). This study uses a value of 0.6 as a reference for the following assessment (Hair et al., 2017).

This study tested the hypothesis with a structural model on the causality relationship between the built variables. This model is seen in its suitability level with the data through the R2 value. Simultaneously, the magnitude of the influence of each variable is tested from the t-values for each path in this inner model (Hair et al., 2017).

\section{Research Results}

\subsection{Description of Research Objects}


Researchers distributed questionnaires distributed via google.doc to various WhatsApp groups researchers and emailed to groups of respondents whom the researcher knew; the number of respondents answered was 312 respondents, but could not use answers to the questionnaire in testing because the respondents answered twice. The data collection period for this study was four months, from November 2020 to February 2021. The final sample tested was 300 respondents. The profile descriptions of the participants are shown in table 1.

\section{Table 1. Sample Description}

\begin{tabular}{|l|c|c|}
\hline \multicolumn{1}{|c|}{ Description } & Frequency & Percentage \\
\hline Gender & & \\
$\quad$ Male & 72 & $24 \%$ \\
Female & 228 & $76 \%$ \\
\hline Total & $\mathbf{3 0 0}$ & $\mathbf{1 0 0 \%}$ \\
\hline Age: & 30 & \\
$\quad<25$ years old & 185 & $10 \%$ \\
26-40 years old & 85 & $28.34 \%$ \\
$\quad>40$ years old & $\mathbf{3 0 0}$ & $\mathbf{1 0 0 \%}$ \\
\hline Total & & \\
\hline
\end{tabular}

From table 1, it can see an overview of the gender and age of the respondents. If seen from the gender of female respondents, there are more than male respondents, namely 228 people $(76 \%)$. Most of the respondents were between 26-40 years old, as many as 185 people $(62 \%)$.

\subsection{Descriptive Statistical Analysis}

The data that has been collected from distributed questionnaires are tabulated to be a data analysis tool. The tabulation results produce a statistical description of the research variables, as shown in Table 2 below:

Table 2. Descriptions of Respondents' Statistics

\begin{tabular}{|l|c|c|c|c|r|}
\hline \multicolumn{1}{|c|}{ Variable } & N & Minimum & Maximum & Mean & $\begin{array}{c}\text { Std. } \\
\text { Devices }\end{array}$ \\
\hline $\begin{array}{l}\text { User Decision on Use } \\
\text { Food Marketplace }\end{array}$ & 300 & 24 & 40 & 33,21 & 1,765 \\
\hline User Interest & 300 & 27 & 40 & 35,45 & 2,311 \\
\hline Ease of use & 300 & 28 & 40 & 37,87 & 2,814 \\
\hline User Security & 300 & 24 & 40 & 33,28 & 1,762 \\
\hline
\end{tabular}


Table 2 shows that the sample $(\mathrm{N})$ was 300 respondents. In the interest variable, the respondent gave the lowest value for the perceived Interest in the Food Marketplace System User of 27, and the highest value was 40. The average respondent gave a value of 35.45 with a standard deviation of 2.311 .

In the convenience variable, respondents gave the lowest value of 28 , and the highest value was 40 , with an average value of 37.87

This table shows that the average research sample believes that the marketplace system is easy to use. As for the safety and intensity variables of using the marketplace platform, the average respondent score is almost the same, namely 33. This figure illustrates that the food marketplace's Security and intensity are relatively high because it exceeds $50 \%$ of the median figure.

From table 2, it can also be seen that all the variables of this study show a standard deviation smaller than the mean value. This value indicates that there is low variation between the maximum and minimum values during the observation period, or in other words, there is not a large enough gap in the variable data quality - this research variable is good data.

\subsection{Data Analysis}

\subsubsection{The Outer Model}

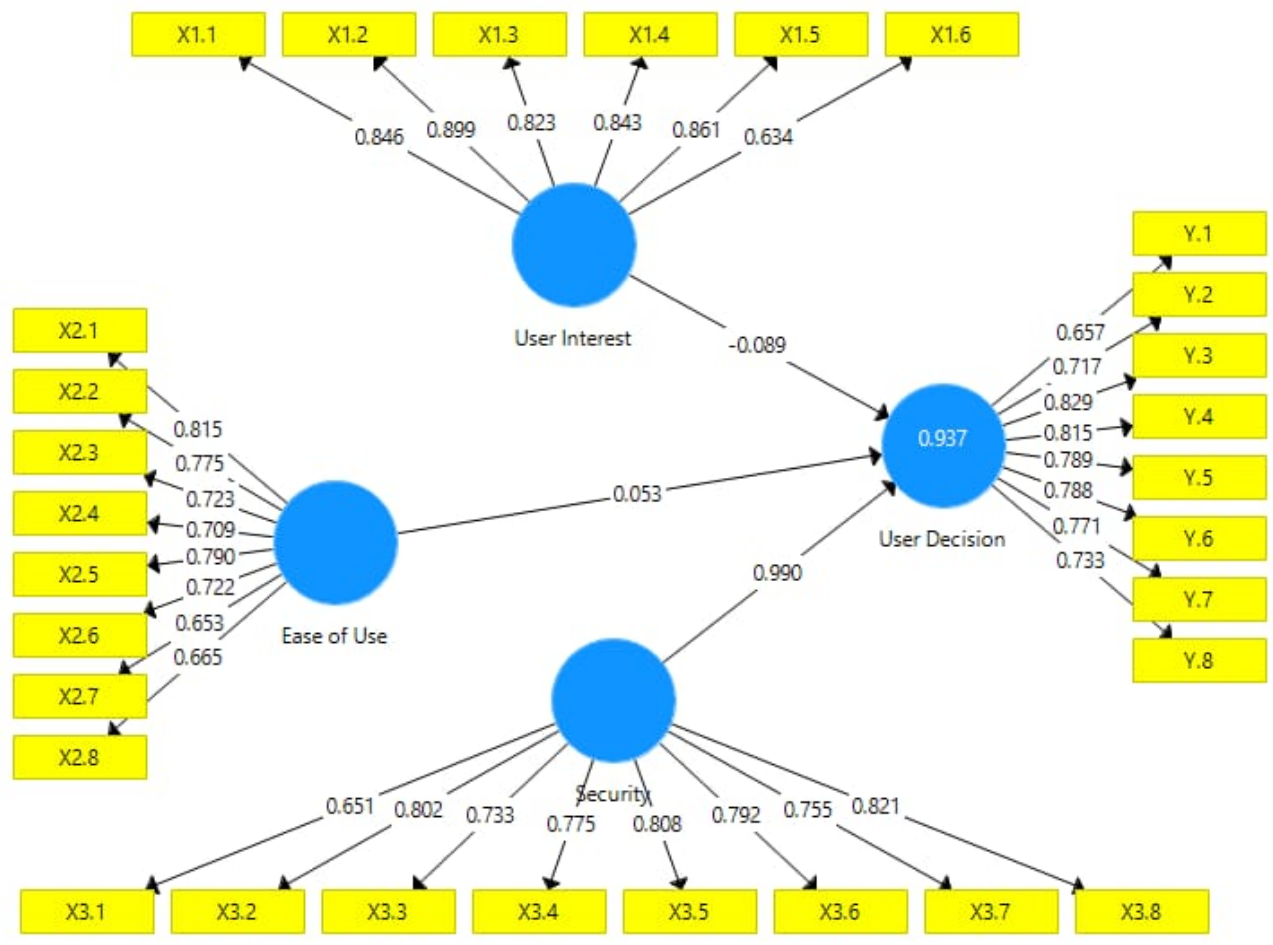

Figure 3. Outer Measurement Model 
From the outer model, we can see the model determination coefficient and the equation model's path coefficient in Figure 1. The standardized loading factor number of all indicators used in this study is above 0.5, concluding that all indicators are valid. Furthermore, these indicators can be used in further testing.

The indicators' convergent validity is assessed based on the indicators' loading factor that measures the construct. The results of the testing shown in Figure 1 and Table 3

\subsubsection{Convergent Validity Result}

Table 3. AVE and communality Value

\begin{tabular}{|l|c|c|}
\hline & AVE & Communality \\
\hline User Interest & 0,676 & 0,676 \\
\hline Ease of Use & 0,538 & 0,538 \\
\hline Security & 0,591 & 0,591 \\
\hline $\begin{array}{l}\text { User Decision Food } \\
\text { Marketplace }\end{array}$ & 0,584 & 0,584 \\
\hline
\end{tabular}

Interest variable has loading factor value and communally number more than required. Likewise, the Ease and intensity of using the food marketplace platform get a number above the requirements. Thus, it can be concluded that all research constructs are valid.

\subsubsection{Discriminant Validity Test Results}

Table 4 presents the test results on the discriminant validity of each research construct indicator.

Table 4. Cross Loading

\begin{tabular}{|l|r|r|r|r|}
\hline & \multicolumn{1}{|c|}{ Ease of Use } & \multicolumn{1}{c|}{ Security } & \multicolumn{1}{c|}{ User Decision } & \multicolumn{1}{c|}{ User Interest } \\
\hline $\mathbf{X 1 . 1}$ & 0.604 & 0.530 & 0.512 & 0.846 \\
\hline $\mathbf{X 1 . 2}$ & 0.630 & 0.581 & 0.534 & 0.899 \\
\hline $\mathbf{X 1 . 3}$ & 0.722 & 0.651 & 0.552 & 0.823 \\
\hline $\mathbf{X 1 . 4}$ & 0.653 & 0.566 & 0.521 & 0.843 \\
\hline $\mathbf{X 1 . 5}$ & 0.665 & 0.549 & 0.503 & 0.861 \\
\hline $\mathbf{X 1 . 6}$ & 0.790 & 0.473 & 0.480 & 0.634 \\
\hline $\mathbf{X 2 . 1}$ & 0.815 & 0.481 & 0.482 & 0.494 \\
\hline
\end{tabular}




\begin{tabular}{|l|l|l|l|l|}
\hline X2.2 & 0.775 & 0.485 & 0.500 & 0.404 \\
\hline X2.3 & 0.723 & 0.458 & 0.486 & 0.316 \\
\hline X2.4 & 0.709 & 0.387 & 0.385 & 0.345 \\
\hline X2.5 & 0.790 & 0.473 & 0.480 & 0.634 \\
\hline X2.6 & 0.722 & 0.651 & 0.552 & 0.823 \\
\hline X2.7 & 0.653 & 0.566 & 0.521 & 0.843 \\
\hline X2.8 & 0.665 & 0.549 & 0.503 & 0.861 \\
\hline X3.1 & 0.722 & 0.651 & 0.552 & 0.823 \\
\hline X3.2 & 0.523 & 0.802 & 0.771 & 0.448 \\
\hline X3.3 & 0.528 & 0.733 & 0.733 & 0.481 \\
\hline X3.4 & 0.590 & 0.775 & 0.683 & 0.541 \\
\hline X3.5 & 0.504 & 0.808 & 0.768 & 0.487 \\
\hline X3.6 & 0.539 & 0.792 & 0.815 & 0.519 \\
\hline X3.7 & 0.440 & 0.755 & 0.789 & 0.479 \\
\hline X3.8 & 0.538 & 0.821 & 0.788 & 0.525 \\
\hline Y.1 & 0.562 & 0.547 & 0.657 & 0.499 \\
\hline Y.2 & 0.521 & 0.633 & 0.717 & 0.439 \\
\hline Y.3 & 0.499 & 0.772 & 0.829 & 0.484 \\
\hline Y.4 & 0.539 & 0.792 & 0.815 & 0.519 \\
\hline Y.5 & 0.440 & 0.755 & 0.789 & 0.479 \\
\hline Y.6 & 0.538 & 0.821 & 0.788 & 0.481 \\
\hline Y.7 & & 0.802 & 0.733 & \\
\hline Y.8 & & & 0.733 & \\
\hline
\end{tabular}

Table 4 shows that the cross-loading value also shows good discriminate validity. The test results show that the correlation value between the indicators against the construct itself exceeds the correlation value with other construct variables.

The table also shows that the Ease of Indicators also has a higher loading factor value than the loading factor with other constructs. The same thing is seen in the Security indicator. Thus, it can be concluded that each indicator distributed to respondents can be understood and can reflect every construct that is appropriately measured.

\subsubsection{Reliability of Indicators}

In addition, The results of the reliability test on all research indicators are presented in Table 5. 


\section{Table 5.}

The Value of Composite Reliability and Cronbach's Alpha

\begin{tabular}{|l|c|c|}
\hline \multicolumn{1}{|c|}{ Construct } & Composite Reliability & Cronbach Alpha \\
\hline User Interest & 0,925 & 0,901 \\
\hline Ease of Use & 0,903 & 0,876 \\
\hline Security & 0,920 & 0,900 \\
\hline $\begin{array}{l}\text { User decision on use of } \\
\text { Food Marketplace }\end{array}$ & 0,918 & 0,898 \\
\hline
\end{tabular}

In Table 5, the researcher presents the level of reliability of each measurement indicator. The test results of the measurement reliability show that all the composite reliability values and Cronbach's alpha were above the requirements in this study. This result means that each question item in the questionnaire is reliable, so that it deserves to be included in the next exam stage.

\section{Structural Model Test}

Figure 4 presents the test results of the structural model. These results indicate the significance level of the relationship between variables in the hypothesis. 


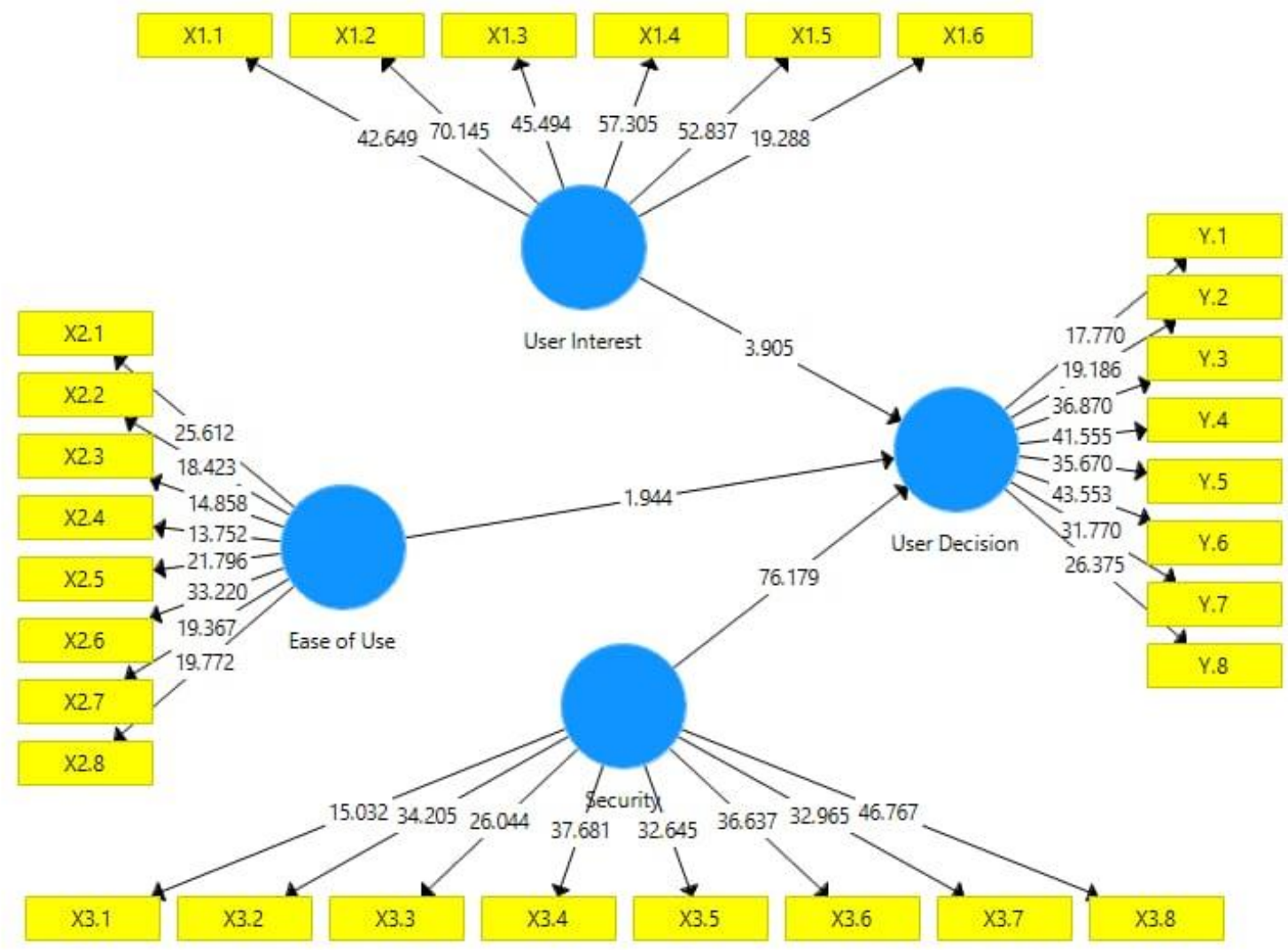

Figure 4. Structural Inner Model

To prove the research hypothesis, it is assessed from the significance of the path coefficient on the structural model in table 6 . Table 6 presents the results of this research hypothesis test.:

Table 6.

\section{Hypothesis test Result}

\begin{tabular}{|c|c|c||c|}
\hline & $\begin{array}{c}\text { original } \\
\text { sample } \\
\text { estimate }\end{array}$ & mean of subsamples & Standarddeviation \\
Statistic \\
\hline $\begin{array}{c}\text { Interest }>\text { Use of Food } \\
\text { Marketplace }\end{array}$ & -0.089 & -0.088 & 0.023 \\
\hline $\begin{array}{c}\text { Ease Of use -> Use of Food } \\
\text { Marketplace }\end{array}$ & 0.053 & 0.051 & 0.027 \\
\hline $\begin{array}{c}\text { Security -> Use of Food } \\
\text { Marketplace }\end{array}$ & 0.990 & 0.992 & 0.013 \\
\hline \hline
\end{tabular}

\subsubsection{Hypothesis test Result}




\section{Testing Hypothesis H1}

The estimated value of the interest variable in table 6 is significant because it is below $5 \%$, and the $\mathrm{t}$-statistic value is 3.905 . This value indicates that food buyers' interest has a significant effect on the Food Market System use. Thus H1 is accepted.

\section{2. $\mathrm{H} 2$ testing}

The convenience variable using the digital food platform has a regression coefficient of 0.053 . This figure means that $\mathrm{H} 2$ is not significant in alpha $5 \%$. Data in the field does not support the second hypothesis of this study. The more convenient and easy for users to use, it does not mean that the intensity of using the food marketplace will be higher.

\section{Testing Results H3}

To see the effect of Security on the Food Market System Use, we can pay attention to the regression coefficient number $\mathrm{H} 3$. The output results show that the security variable has an estimated value of 0.990 and is significantly below $5 \%$. These results indicate that a high level of security will increase the intensity of marketplace use.

\subsection{Discussion}

\subsubsection{The Ease of Use on Using of the Food Marketplace System in the New Normal Covid-19 Era}

Based on testing the first hypothesis, we can conclude that the Food Marketplace System Users' Interests variable effect. This study's results are different from Maria's (2019) study, which failed to prove the impact of Interest on purchasing decisions.

The test results in this study indicate a significant influence on the respondent's Interest in users of the Food Marketplace System in Indonesia. In the New Normal Covid-19 era, people changed their Interest in the food marketplace and influenced them to decide to use food applications instead of transacting manually. This factor also supports government regulations to maintain distance and reduce going out of the house. People prefer to buy food online through a food marketplace application that is widely available and easy to use.

\subsubsection{Effect of convenience on Users of the Food Marketplace System in the New Normal Covid-19 Era}


Based on testing the second hypothesis, we can conclude that the convenience variable does not affect the Food Marketplace System Users. This study's results are inconsistent with Maria's (2019) research, which explains that Ease of transaction occurs when a person feels that he does not need to spend a lot of effort to influence the use of this new technology. Ease of use when consumers don't need a lot of energy to receive information about the products they want and find it easy to shop at the food marketplace.

This research fails to prove that the Ease of using the Food Marketplace improves using food platforms. Making consumer decisions using and transacting in the food marketplace in the current new normal covid-19 era is not based on the Ease of access to the system. This situation is possibly influenced by the fact that most respondents are millennial-aged between 20 and 40 years, as much as $61.66 \%$. This millennial group of people may not find it difficult to use gadgets because they are used. The online marketplace platform available in Indonesia has proven to be very easy to use, so it doesn't pose a problem for users. Thus most respondents still find it easy to transact food through the food marketplace application.

\subsubsection{The effect of Security on Users of the Food Marketplace System in the New Normal Covid-19 Era}

The test results of the third hypothesis indicate that the transaction security variable positively affects the Food Marketplace System Users. The potential crimes that usually occur in online transactions have been well accommodated by platform providers so that users feel comfortable transacting. According to user perceptions, the Security of the marketplace infrastructure is sufficient to encourage their desire to continue using this food marketplace platform.

This study's results are in line with Maria (2019), who found that Security positively influences the decision to buy goods through the Shopee marketplace. Users of the Food Marketplace System feel that transacting through this platform does not cause any problems, so they trust and decide to continue using it. Users of the Food Marketplace System feel that their data and funds are adequately secured so that consumers make decisions to use the food marketplace in the new normal covid-19 era for transactions.

\section{Conclusions and Suggestions}

This study provides empirical evidence regarding Interest, Ease, and Security on Users of the Food Marketplace System.. The research sample was taken from 300 respondents from all regions in Indonesia, the User Community of the Food Marketplace System. User interest is proven to influence the User of the Food Marketplace System. On the other hand, Ease does not affect the Food 
Marketplace System Users. Security has a positive effect on Food Marketplace System Users. Users of the Food Marketplace System feel safe and influence the decision to use the food marketplace in the new normal covid-19 era.

Researchers have carried out all the steps carefully in order to get the best results. However, the researchers admit that there are still some limitations that need to be considered in interpreting these results. First, the inherent limitations of the data obtained through questionnaires are due to differences in the authors' perceptions and the research respondents. Although it has been minimized by conducting a preliminary test, this limitation will still exist in research that uses primary data. Second, the research model only tests the effect of variables/constructs linearly. The results are still possible to research by examining the relationship between variables and describing the effect as a whole.

Future research is expected to carry out further testing with the weighted least square model by increasing the number of samples in order to provide a more comprehensive picture of the results. Current research respondents are not limited to users of certain marketplace applications. Future research can develop by examining certain platform users, for example, by distinguishing between users of web-based platforms and those already based on standalone applications so that a more comprehensive picture is obtained.

\section{BIBLIOGRAPHY}

Adhi Prakosa (2021). An Analysis of Online Shoppers' Acceptance and Trust toward Electronic Marketplace using TAM Model.Journal of Physics Conference Series 1823(1):012008. DOI:10.1088/17426596/1823/1/012008

Assael, Henry. 2001. Consumer Behavior and Marketing Action. 6 th ed. Natorp Blvd, Mason: South-Western College Publishing. Pp 282-284

Chang, Y.-W., Hsu, P.-Y. and Yang, Q.-M. (2018), "Integration of online and offline channels: a view of O2o commerce”, Internet Research, Vol. 28 No. 4, pp. 926-945.

Chin, Wynne. W., and Todd, Peter, A., 1995, "On the Use, Usefulness, and Ease of Use A Structural Equation Modeling in MIS Research: A Note of Caution," MIS Quarterly, June

Christoph Busch. 2021. Rethinking Product Liability Rules for Online Marketplaces: A Comparative Perspective. Product Liability for Online Marketplaces.

https://www.academia.edu/45372084/Rethinking_Product_Liability_Rules_ for_Online_Marketplaces_A_Comparative_Perspective (assessed, 09/04/2021). 
Davis, Fred D., (1989), "Perceived Usefulness, Perceived Ease of Use, and User Acceptance of Information Technology," MIS Quarterly, September, pp.319- 340

Davis, Fred D., Bagozzi, Richard P., dan Warshaw, Paul R., (1989), "User Acceptance Of Computer Technology: A Comparison Two Theoretical Models" Management Science, August, pp.982-1003

Hair, J.F., Hult, G.T.M., Ringle, C.M. and Sarstedt, M. (2017) A Primer on Partial Least Squares Structural Equation Modeling (PLS-SEM), 2nd ed., SAGE, Thousand Oaks, CA

Huifang Li. Yulin Fang. Kai H. Lim. Youwei Wang. 2018. Platform-Based Function Repertoire, Reputation, and Sales Performance of E-Marketplace Sellers. MIS Quarterly 43(1). DOI: 10.25300/MISQ/2019/14201

Igbaria, M., T. Guimaraes, and G. Davis. 1995. "Testing the determinants of microcomputer usage via a structural equation model." Journal of Management Information Systems 11, no. 4: 87-114.

Kestenbaum, 2017.

https://www.forbes.com/sites/richardkestenbaum/2017/04/26/what-are-

online-marketplaces-and-what-is-their-future/?sh=4bf76a003284 (Accessed 10/04/2021).

Lavie, D. (2006), "The competitive advantage of interconnected firms: An extension of the resource-based view", Academy of Management Review, Vol. 31 No. 3, pp. 638-658.

Liu, M.F. Gong, Z. Chen, L. Yang, and H. Lu, 2020. "Antecedents of Mobile Shopping Adoption in the Information Age," IOP Conf. Series: Materials Science and Engineering $750 \quad$ (2020) 012051 IOP Publishing doi:10.1088/1757-899X/750/1/012051

Li Chen \& Fengxia Zhu (2021): Seller information sharing in online marketplaces, Journal of Marketing Management, DOI: 10.1080/0267257X.2021.1900895

Liu, X. (2016), "Vertical integration and innovation", International Journal of Industrial Organization, Vol. 47, pp. 88-120

M. Ridwan, T. Militia, and G. N. Achmad, "How Trust and Quality of Information Affect Buying Interest and Purchasing Decision? Study on Shopee Customers in Samarinda," Int. J. Econ. Bus. Account. Res., vol. 4, no. 1, pp. 95-102, 2020.

Mayasari M, Audina Audina. 2020. The Influence of E-Service Website ECommerce Quality to E-Customer Satisfaction. Proceedings of the First International Conference on Applied Science and Technology (iCAST 2018). Advances in Social Science, Education and Humanities Research, volume 298 
Parasuraman, A V. Zeithaml, and A. Malhotra. "E-S-QUAL: a multiple-item scale for assessing electronic service quality". Journal of Service Research, Vol. 7 No. 3, pp. 213-233, 22. 2007.

Tian L., Vakharia A.J., Tan Y., Xu Y., 2018. Marketplace, Reseller, or Hybrid: Strategic Analysis of an Emerging E-Commerce Model. Production and Operations Management, 27(8), 1595-1610. http://doi.org/10.1111/poms.12885.

Valtteri Kaartemo, Anna-Greta Nyström. 2020. Emerging technology as a platform for market shaping and innovation. Journal of Business Research, https://doi.org/10.1016/j.jbusres.2020.10.062)

Wan, X., Chen, J. and Chen, B. (2020), "Exploring service positioning in platform-based markets," International Journal of Production Economics, Vol. 220, pp. 1-11.

Weiss, MM. B.V. Glenn, and G. Dhruv. "Determinants of Online Channel Use and Overall Satisfaction with a Relational, Multichannel Service Provider." Journal of the Academy of Marketing Science. 2003.

Wang.S and N. P. Archer. Electronic marketplace definition and classification: literature review and clarifications. Enterprise Information Systems, Vol. 1, No. 1, February 2007, 89-112. DOI: 10.1080/17517570601088380

Wan, X. and Chen, J. (2019), "The relationship between platform choice and supplier's efficiency evidence from China's online to offline $(\mathrm{O} 2 \mathrm{O})$ Ecommerce platforms", Electronic Markets, Vol. 29 No. 2, pp. 153-166.

Wan, X., Chen, J. and Chen, B. (2020), "Exploring service positioning in platform-based markets," International Journal of Production Economics, Vol. 220, pp. 1-11.

Wei, K., Li, Y., Zha, Y. and Ma, J. (2019), "Trust, risk and transaction intention in consumer-to-consumer e-marketplaces: An empirical comparison between buyers' and sellers' perspectives", Industrial Management \& Data Systems, Vol. 119 No. 2, pp. 331-350. https://doi.org/10.1108/IMDS-10-2017-0489

Xing Wan; Nianxin Wan; Ben Shaw-Ching Liu. 2020. Impact of O2O platform multihoming and vertical integration on performance of local service firms - a quantile regression approach. Internet Research Vol. 30 No. 5, 2020 pp. 1583-1610 @ Emerald Publishing Limited 1066-2243 DOI 10.1108/INTR03-2019-0087

Xing Wan; Nianxin Wan; Ben Shaw-Ching Liu. 2020. Impact of O2O platform multihoming and vertical integration on performance of local service firms - a quantile regression approach. Internet Research Vol. 30 No. 5, 2020 pp. 1583-1610 @ Emerald Publishing Limited 1066-2243 DOI 10.1108/INTR03-2019-0087 
Zhi Yang; Zihe Diao; Jun Kang. 2020. Customer management in Internet-based platform firms: review and future research directions. May 2020. Marketing Intelligence \& Planning ahead-of-print (ahead-of-print). DOI: 10.1108/MIP01-2020-0012

https://dailysocial.id/post/startup-marketplace-bahan-pangan-tokowahab-pilihtumbuh-secara-organik Downloaded November 2020

https://dailysocial.id/post/sederet-aplikasi-belanja-online-terpopuler-selamapandemi Downloaded November 2020 